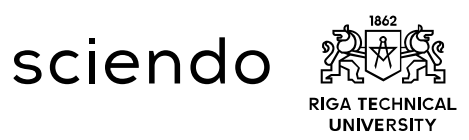

\title{
LATVIAN HIGH-TECH INDUSTRY: TRENDS AND DEVELOPMENTS
}

\author{
Joseph MENAKER ${ }^{1}$, Velga OZOLIN,A ${ }^{2}$ \\ 1 "UAV factory USA" LLC, New York, USA \\ ${ }^{2}$ Riga Technical University, Riga, Latvia \\ Corresponding author's e-mail: velga.ozolina@rtu.lv
}

\begin{abstract}
The paper covers analysis of high-tech industry development in Latvia, as well as its facilitating and restricting factors. High-tech industries become more important in Latvia both in terms of export share and generated value added; also the number of enterprises and employees is increasing. A stable political system, enabling business environment, a relatively low corporate income tax rate, and government aid are considered as some of the most important facilitating factors. The paper emphasizes the government's role in promoting and developing the high-tech manufacturing. The most significant limitations are the lack of skilled specialists and sophisticated real estate space, and the remote industrial supply companies and the service centres. Recommendations are given on the possible development directions, including improvements in manufacturing infrastructure, enhancements of the skill level of the labour force, and bringing up a new generation of entrepreneurs.
\end{abstract}

Keywords: Advanced manufacturing, entrepreneurship in Latvia, high-tech industry, high-tech industry influencing factors, skilled labor.

JEL Classification: E01; L60; O14.

\section{INTRODUCTION}

Industries that produce high-technology products are considered to be high-tech industries. Eurostat (Basarac Sertić, Vučković, \& Škrabić Perić, 2015) defines high-tech industries as the manufacture of basic pharmaceutical products and pharmaceutical preparations (NACE rev.2, division 21), the manufacture of computer, electronic and optical products (division 26), and the manufacture of air and spacecraft and related machinery (division 30.3). Organisation for Economic Co-operation and Development (OECD) uses similar approach within the standard international trade classification (SITC) classification. This excludes manufacturers of automobiles and industrial equipment, even though some of them are quite hightech, as well as telecommunication companies.

High-tech industries are significant for any economy. They ensure production of exportable products, enhance international competitiveness of countries, attract qualified labor force, and ensure production of high value-added products and other benefits. They are related to complex processing of raw materials, innovative activities, etc.

In Latvia, development directions of high-tech industries are defined in several development planning documents, as the Guidelines for Science, Technology 
Development and Innovation for 2014-2020 (Ministry of Education and Science, 2013), which include the Smart Specialization Strategy.

It is the common knowledge now that high-tech manufacturing is a very valuable sector of manufacturing, because it provides the prosperity to society, innovation and fast growth and has a pretty high rate of survivability during the downturns.

Some researchers (Romero \& McCombie, 2016) suggest that the high-tech manufacturing industries exhibit larger returns to scale than the low-tech ones. These industries can facilitate the overall growth of productivity.

High-tech industries have higher requirements for technology innovation, the growth of high-tech industries can be promoted in agglomeration, as in such circumstances the knowledge and technology information can be spread more quickly and thus the speed of innovation is improved (Ruan \& Zhao, 2011).

In a way, high-tech industries are more "independent" - they usually are less related to other industries of the national economy, when compared with mediumhigh- and low-tech industries.

The paper analyses the data of the Latvian high-tech industries. It provides analysis of basic pharmaceutical products and pharmaceutical preparations (division 21), more extensively the manufacture of computer, electronic and optical products (division 26), and the manufacture of air and spacecraft and related machinery (division 30.3) upon the availability of data.

On the basis of the analysis, the paper aims to reveal problems related to the development of high-tech industries in Latvia and their possible solutions.

The paper is based on the experience of the authors in organizing and managing production in high-tech industry enterprises in Latvia from 1990 till nowadays.

\section{ANALYSIS OF THE HIGH-TECH INDUSTRIES IN LATVIA}

\subsection{Scope and Dynamics}

Before restoration of Latvian independence, high-tech manufacturing was dominated by such huge enterprises as VEF, ALFA, "Komutators", and "Radiotehnika". During those times, such enterprises by some estimates represented $45-55 \%$ of the Latvian manufacturing sector. In their best years, VEF and ALFA, for example, employed over 20000 and 10000 employees, respectively. Approximately $80 \%$ of the high-tech manufacturing sector products were consumed by the military, mostly from the Soviet Union and Warsaw Pact countries. Currently, these industries have a narrower spectrum and a much smaller share in the economy. These industries are mainly located in Riga and Pieriga regions (Auzina-Emsina \& Ozolina, 2017).

Latvia still has a relatively small share of high-tech products in total exports of goods. In 2015, it was 9.8\%. In comparison, in Germany, it was 14.8\%, in Denmark $-10.7 \%$, in Ireland $-24.0 \%$, in France $-21.6 \%$, in the Netherlands $20.0 \%$, in Luxemburg $-19.7 \%$, in Cyprus $-19.3 \%$, in Estonia $-15.4 \%$, and in Lithuania $-7.5 \%$. The average share of the EU-28 in extra-EU28 exports was $17.0 \%$; for Latvia it was $11.7 \%$ (Eurostat, 2018). 
In 2016, there were 204 enterprises assigned to the high-tech industries, which is $1.9 \%$ of the enterprises in manufacturing (see Table 1). The larger number of enterprises operates in several sub-sectors of the manufacture of computer, electronic and optical products and the manufacture of pharmaceutical preparations. The overall number of high-tech enterprises is constantly increasing since 2010, and the same trend applies to the share of the high-tech enterprises in the number of enterprises in manufacturing in Latvia (with the exception of 2013). This trend is evident also in several sub-sectors, for example, the manufacture of electronic components and the manufacture of consumer electronics.

Table 1. Number and Dynamics of Enterprises in High-Tech Industries in Latvia (CSB, 2018)

\begin{tabular}{|c|c|c|c|c|c|c|c|c|}
\hline $\begin{array}{l}\text { NACE } \\
\text { rev. } 2 \\
\text { code }\end{array}$ & Industry & 2010 & 2011 & 2012 & 2013 & 2014 & 2015 & 2016 \\
\hline \multirow[t]{2}{*}{$\mathbf{C}$} & Manufacturing - total & 7872 & 7737 & 8981 & 9537 & 9806 & 10523 & 10991 \\
\hline & High-tech industries, including: & 133 & 140 & 167 & 168 & 177 & 192 & 204 \\
\hline C21 & $\begin{array}{l}\text { Manufacture of basic } \\
\text { pharmaceutical products and } \\
\text { pharmaceutical preparations }\end{array}$ & 27 & 26 & 26 & 27 & 29 & 28 & 33 \\
\hline $\mathrm{C} 26$ & $\begin{array}{l}\text { Manufacture of computer, } \\
\text { electronic and optical products, } \\
\text { including: }\end{array}$ & 104 & 110 & 135 & 136 & 142 & 155 & 159 \\
\hline C261 & $\begin{array}{l}\text { Manufacture of electronic } \\
\text { components and boards }\end{array}$ & 18 & 22 & 28 & 32 & 32 & 35 & 37 \\
\hline $\mathrm{C} 262$ & $\begin{array}{l}\text { Manufacture of computers and } \\
\text { peripheral equipment }\end{array}$ & 22 & 21 & 30 & 26 & 28 & 29 & 31 \\
\hline $\mathrm{C} 263$ & $\begin{array}{l}\text { Manufacture of communication } \\
\text { equipment }\end{array}$ & 20 & 21 & 24 & 23 & 26 & 25 & 23 \\
\hline $\mathrm{C264}$ & $\begin{array}{l}\text { Manufacture of consumer } \\
\text { electronics }\end{array}$ & 4 & 8 & 14 & 18 & 18 & 23 & 21 \\
\hline C265 & $\begin{array}{l}\text { Manufacture of instruments and } \\
\text { appliances for measuring, } \\
\text { testing and navigation; watches } \\
\text { and clocks }\end{array}$ & 33 & 33 & 34 & 33 & 33 & 39 & 42 \\
\hline C303 & $\begin{array}{l}\text { Manufacture of air and spacecraft } \\
\text { and related machinery }\end{array}$ & 2 & 4 & 6 & 5 & 6 & 9 & 12 \\
\hline
\end{tabular}

In 2016, high-tech enterprises employed more than 4000 employees, of which $3.5 \%$ were the employees in manufacturing (see Table 2). General trends here are similar as in the number of enterprises. However, it is important to note that the number of employees in several sub-sectors decreased dramatically during the crisis (mostly in 2009-2010), for example, the manufacture of pharmaceutical preparations, the manufacture of communications equipment, and the manufacture of consumer electronics. The number of employees per enterprise in high-tech industries on average is not high. In 2016, the ratio of the number of employees to 
the number of enterprises was mostly between 1.8 and 26.7, with the exception of the manufacture of pharmaceutical preparations, where the number was 70 .

Table 2. Number and Dynamics of Employees in High-Tech Industries in Latvia (CSB, 2018)

\begin{tabular}{|c|c|c|c|c|c|c|c|c|}
\hline $\begin{array}{l}\text { NACE } \\
\text { rev. } 2 \\
\text { code }\end{array}$ & Industry & 2010 & 2011 & 2012 & 2013 & 2014 & 2015 & 2016 \\
\hline \multirow[t]{2}{*}{$\mathbf{C}$} & Manufacturing - total (thsd.) & 108.7 & 112.2 & 118.3 & 120.8 & 121.7 & 119.4 & 118.4 \\
\hline & High-tech industries, including: & 2967 & 3149 & 3456 & 3593 & 3769 & 3933 & 4092 \\
\hline C21 & $\begin{array}{l}\text { Manufacture of basic } \\
\text { pharmaceutical products and } \\
\text { pharmaceutical preparations }\end{array}$ & 1714 & 1887 & 1976 & 2033 & 2038 & 2042 & 2114 \\
\hline $\mathrm{C} 26$ & $\begin{array}{l}\text { Manufacture of computer, } \\
\text { electronic and optical products, } \\
\text { including: }\end{array}$ & 1240 & 1246 & 1449 & 1519 & 1674 & 1817 & 1884 \\
\hline C261 & $\begin{array}{l}\text { Manufacture of electronic } \\
\text { components and boards }\end{array}$ & 365 & 401 & 497 & 566 & 648 & 675 & 758 \\
\hline $\mathrm{C} 262$ & $\begin{array}{l}\text { Manufacture of computers and } \\
\text { peripheral equipment }\end{array}$ & 72 & 51 & 60 & 61 & 61 & 78 & 71 \\
\hline $\mathrm{C} 263$ & $\begin{array}{l}\text { Manufacture of } \\
\text { communication equipment }\end{array}$ & 324 & 335 & 369 & 376 & 395 & 427 & 434 \\
\hline $\mathrm{C} 264$ & $\begin{array}{l}\text { Manufacture of consumer } \\
\text { electronics }\end{array}$ & 77 & 62 & 117 & 80 & 105 & 101 & 96 \\
\hline $\mathrm{C} 265$ & $\begin{array}{l}\text { Manufacture of instruments } \\
\text { and appliances for measuring, } \\
\text { testing and navigation; watches } \\
\text { and clocks }\end{array}$ & 326 & 319 & 335 & 371 & 388 & 456 & 441 \\
\hline C303 & $\begin{array}{l}\text { Manufacture of air and } \\
\text { spacecraft and related machinery }\end{array}$ & 13 & 16 & 31 & 41 & 57 & 74 & 94 \\
\hline
\end{tabular}

More than $90 \%$ of all the employees are full-time employees in all the hightech industries.

The share of the value added of high-tech industries (except the manufacture of air and spacecraft and related machinery) in manufacturing has grown from $5.1 \%$ in 2010 to $8.4 \%$ in 2015 (see Fig. 1). These fluctuations go in line with the fluctuations of the generated value added, which decreased in 2014 in both industries, but then grew again, especially in the manufacture of computer, electronic and optical products, where the value added doubled in 2015 as compared to 2014 . 


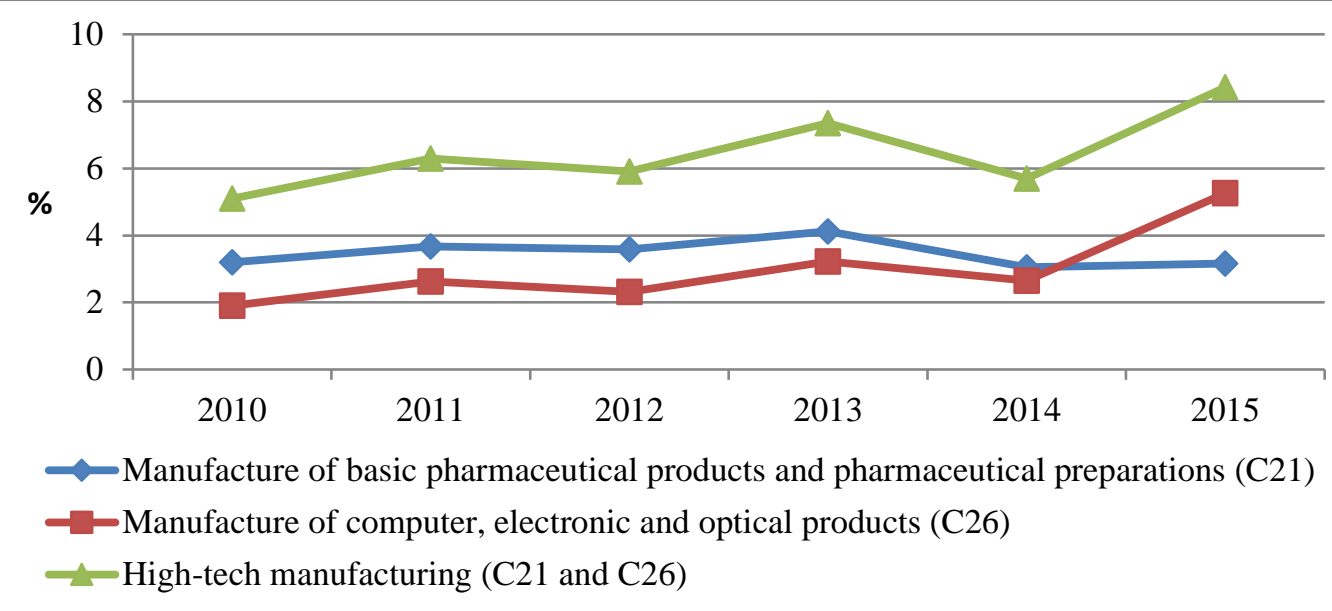

Source: authors' calculations based on CSB (2018) database data.

Fig. 1. The share of high-tech industries in the value added of manufacturing, $\%$.

Using the available data, it is possible to evaluate the productivity expressed as the real value added per hour worked in two major high-tech industries. As compared to the productivity in manufacturing, both high-tech industries have higher values (see Fig. 2). Productivity growth is more stable in the manufacture of electronic and optical products, and in 2015, it was four times higher than in manufacturing. Thus, many enterprises in high-tech industries can be considered as successful in ensuring productivity increase and growth. Moreover, there is a relationship between the productivity and exports, therefore increased productivity ensures higher competitiveness in export markets (Počs \& Ozoliņa, 2016).

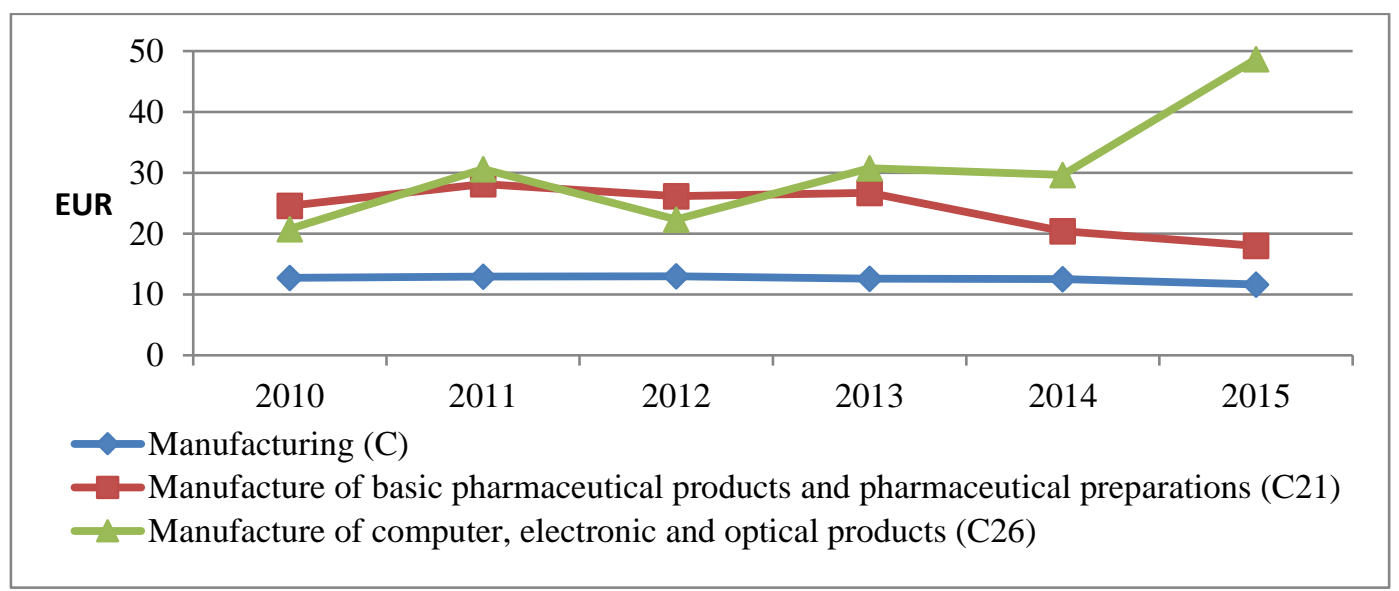

Source: author's calculations based on CSB (2018) database data.

Fig. 2. Dynamics of the real value added per hour worked in 2010-2015, EUR.

Success of the high-tech industries in Latvia can be illustrated with some examples of enterprises working in the high-tech industries. In the manufacturing of basic pharmaceutical products and pharmaceutical preparations, two large 
enterprises stand out: JSC "Grindeks", a manufacturer of original, generics and active pharmaceutical ingredients (in 2016, the net turnover was EUR 105 m, 1285 employees (AS Grindeks, 2017)), and JSC "Olainfarm", a manufacturer of chemical and pharmaceutical products (in 2016, the revenues were EUR $111 \mathrm{~m}$, 1798 employees (Nasdaq \& Morningstar, 2018)). There are several successful enterprises in the manufacture of computer, electronic and optical products. Examples: "Mikrotik", a manufacturer of computer equipment (in 2015, the revenues were EUR 202 m, 160 employees), "Draugiem LV", a cooperative of innovative ideas, and a manufacturer of smart home products, telemetry, etc. (in 2015, the revenues were EUR 23 m, 250 employees), "HansaMatrix", a contract electronics manufacturer (in 2015, the revenues were EUR 13 m, 240 employees), "Rīgas Elektromašīnbūves Rūpnīca", a manufacturer of electric machines and machinery for passenger trains (in 2015, the revenues were EUR $13 \mathrm{~m}, 552$ employees), "SAF Tehnika", a manufacturer of digital microwave radio data transmission equipment (in 2015, the revenues were EUR 12 m, 183 employees), "ISP Optics Corporation", a manufacturer of high-precision optical components (in 2016, the revenues were EUR 13 m, 110 employees), and "GroGlass", a developer and manufacturer of high-performance AR coatings for glass and acrylics (in 2015, the revenues were EUR $8 \mathrm{~m}$ ). In the manufacture of air and spacecraft and related machinery, the largest/most successful enterprise is "UAV Factory", a designer and manufacturer of UAV platforms (in 2016, the revenues were EUR $3 \mathrm{~m}, 65$ employees) (Lursoft, 2018).

\subsection{Contributing Factors}

There are several factors that have contributed to the development of high-tech industries, such as science and technological development, investment, cooperation between the science and business sectors, education system, labor availability, innovative activities, and many others. These factors can be different in each country. Situation analysis indicates that in Latvia, an important group of factors is related, first of all, to the public sector - government and macro-economic level. The most important of these factors are:

- a stable political system and an enabling business environment. Latvia ranked 20th in the Index of Economic Freedom by the Heritage Foundation in 2017 (The Heritage Foundation, 2018). The index is based on the country rule of law, government scale, efficiency of regulation, and market openness. In 2017, Latvia occupied the 14th place in the World Bank's "Doing Business" rating (The World Bank, 2018);

- a relatively low corporate income tax rate. The Latvian corporate tax rate for 2018 is $20 \%$ which is still lower than the corporate tax rate in the USA (21\%, without local taxes) and in the most of the developed European economies (Deloitte, 2018). For example, in Germany, the corporate tax rate is around 30\% (including local taxes), in France $-33.3 \%$, in Spain $-25 \%$;

- government aid through government agencies like the Investment and Development Agency of Latvia (LIAA), the financial institution ALTUM, and others. 
Regarding the last factor, for example, cooperative partnerships of "ISP Optics" with the government agency LIAA have provided over 500,000 euros of subsidies aimed at bolstering employee training and upgrading equipment. Another successful Latvian start-up, "UAV Factory", for the last five years received almost 1 million euros, out of which $84 \%$ of the total amount were directed towards various R\&D projects, $9 \%$ - for marketing, and 7\% - for capital expenditures.

Loyal, skilled, creative, well-educated and disciplined workforce is another major factor for success in Latvia. For example, in "ISP Optics", over 50\% of employees have higher education degrees. Moreover, the core employees in Riga have an average of 15 years' experience at "ISP Optics" and 23 years of experience in the optical industry.

The important and critical factor for the development of high-tech industry is modern industrial infrastructure. The industrial infrastructure is of very high cost and requires high level of investments in its maintenance. In Latvia, and especially in its capital Riga, the access to the comprehensive electrical grid, water, sewage, transportation and Internet is easily available. For example, according to the Akamai State of the Internet reports, until the 3rd quarter of 2016, Latvia was in the top-ten worldwide list by the average Internet speed (Akamai, 2016).

No successful advanced manufacturing and start-ups can flourish without access to capital, financing and proper accounting system. Latvia has one of the most developed financial institutions in Eastern Europe with a sophisticated banking system, including multicurrency accounts, availability of different forms of capital equipment leasing and borrowing. Scandinavian banks are predominantly represented in the Latvian banking industry. In terms of accounting, the "Big Four" accounting companies (PwC, "Deloitte", "Ernst \& Young", and KPMG) and BDO have their offices in Latvia. Latvian accounting system is based on international financial reporting standards (IFRS), which are steady converging with the American generally accepted accounting principles (GAAP).

\subsection{Development Limitations}

Despite the significant factors, which facilitate the development of the hightech industries, there are a lot of factors limiting the growth of Latvian high-tech manufacturing. The most significant one is the lack of specialists. Despite the high demand, there is a huge deficit of the skilled labor especially technicians who are able to perform such functions as CNC operators, quality controllers, sophisticated electronics specialists and assemblers. For example, both "ISP Optics" and "UAV Factory" have dozens of open positions, which are staying unfilled for years. Practically, no trade school or apprenticeship programs exist to train modern labor force. In these conditions, most of training is done on the job, and dilutes companies' resources. The situation is much worse with the design and production engineers. The existing higher education institutions very often lack the connection with the start-up manufacturing companies and sometimes prepare students based on the outdated job requirements.

The most critical situation is with the sales and marketing specialists who are able to do international sale. Keep in mind that most of the products manufactured in high-tech manufacturing sector are export oriented. According to the CSB data 
(CSB, 2018), more than $85 \%$ of the products of manufacture of basic pharmaceutical products and pharmaceutical preparations (in 2008) and more than $92 \%$ of the products of manufacture of computer, electronic and optical products (in 2014) are exported (in 2017, these shares are probably even higher, as the share of exported products of manufacturing industry is gradually rising since 2008 and in 2017 is $65 \%$ as compared with $50 \%$ in 2008). As an alternative to the current labor situation, "UAV Factory" and "ISP Optics" started to import sales specialists and designers from Western Europe, which put immense pressure on the existing cost structures and the global competitiveness.

Each year more than 1800 students graduate from higher education institutions and colleges in the field of engineering, manufacturing and construction, and more than 1000 students - in natural sciences, mathematics and information technologies (see Fig. 3). The number of graduates in engineering, manufacturing and construction has moved back to the level of 2002-2008 after an optimistic upward trend in 2009-2012. The number of graduates in natural sciences, mathematics and information technologies is more stable, although the number is slightly decreasing since 2012 in line with the decrease in the total number of graduates. Therefore, it is clear that the local graduates will not satisfy the growing need for skilled labor.

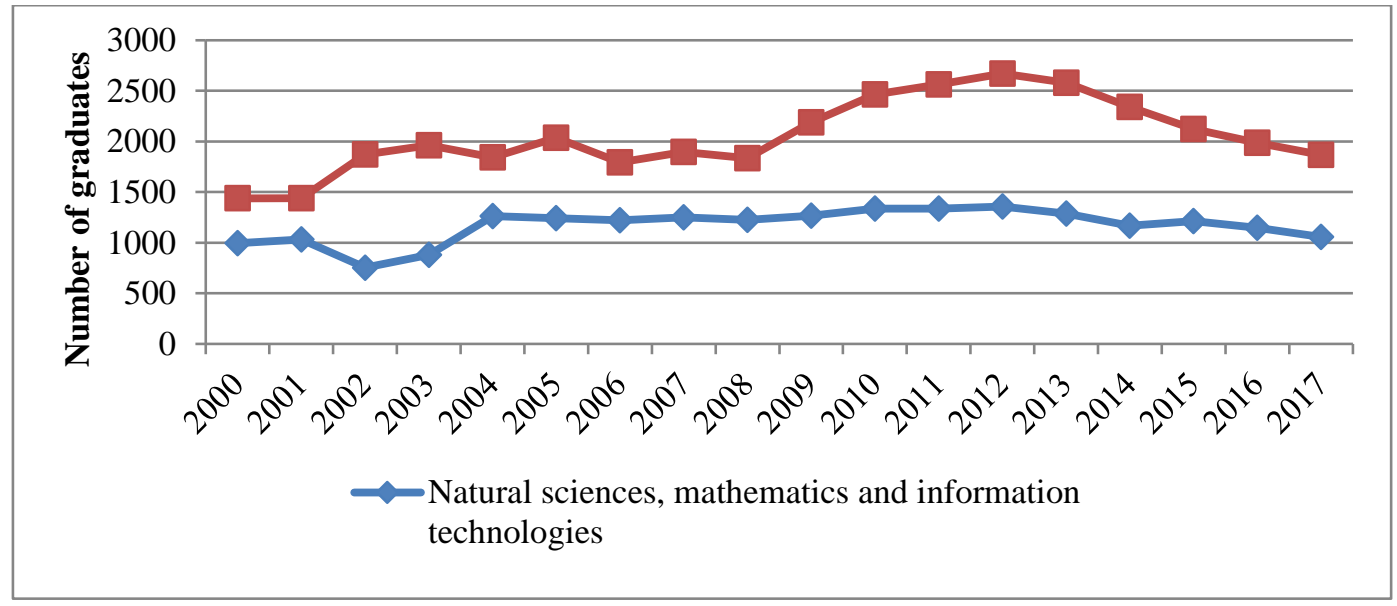

Fig. 3. Graduates with a degree or a qualification in higher education institutions and colleges of Latvia in selected education thematic groups (CSB, 2018).

One of the important tools used in Silicon Valley to attract the new talent for start-ups is the employee stock options plan (ESOP)). Based on our personal experience, we learned that there is no adequate legal mechanism to award stock options to employees in Latvian laws. As an alternative, some Latvian start-ups are trying to register the holding company in Delaware, USA, or to modify ESOP into success-sharing plans.

High-tech manufacturing requires sophisticated real estate space with developed infrastructure and flexible layouts. Unfortunately, in Latvia, it is very difficult to find real estate that can meet the requirements of high-tech manufacturing. Manufacturing real estate inventory mostly consists of old Sovietstyle concrete buildings with six meters high ceilings, very inefficient, and in a bad 
shape. For example, based on the 2017 Collier International report, among 10 biggest real estate deals in Riga, there were two warehouse projects, three office projects, two retail spaces, and two mixed-use projects (Colliers International, 2018). No new industrial space was in the list.

The industrial supply companies and the service centers are important to maintain uninterrupted production for the high-tech manufacturing. Unfortunately, due to the market size, there are no offices of any significant European or American industrial suppliers such as "McMaster-Carr", "MSC Industrial Supply", "IPH Group" or EDIS. These types of companies in the industrialized nations are able to deliver critical parts to the manufacturing floor within the hours. In the service centers, the presence of the large CNC machine manufacturers such as HAAS, "Okuma" and "Mazak" is very limited. The service of the diamond turning machines necessary to make high-precision optics is not available in Latvia, and the service calls are placed through UK or US centers, which prolongs the idle time of the non-operational lathes.

\section{OPPORTUNITIES AND CHALLENGES}

\subsection{Role of Public Sector}

To assure the success of the high-tech manufacturing in Latvia, the government intervention is required. The LIAA experience in creation of incubators and supporting start-ups should be publicized, supported and expanded. The government may take a more proactive role in creation of favorable conditions to attract sophisticated labor and specialists through the immigration policy. Also, it is necessary to modernize legal and tax aspects and create a mechanism to grant stock options in the start-ups in order to create incentives to retain talented specialists.

The future of high-tech manufacturing will also depend on the focused, complex government programs helping new start-ups survive and succeed (like ALTUM programs for the support of start-up companies and their education, support from the municipalities, etc.).

Also, Latvian high-tech industry has to adapt to the reality of the fourth industrial revolution or "Industry 4.0". The development of the "Industry 4.0" is related to the development of the Internet, more precisely, its expanding role as more and more products are connected to the Internet, there is a wide presence of sensors, wireless communications expand, robot and intelligent machines are rapidly developing, and real-time data analysis is done more frequently (Stăncioiu, 2017). All these things have the potential to change the way the products are made. The faster the enterprises can adapt to these new circumstances, the higher their development potential.

In order to succeed, it is necessary to overcome the limitations and have a clear strategy and vision of what is Latvian high-tech manufacturing of the future.

The current Smart Specialization Strategy aims at increasing the innovation capacity and developing the innovation system, which facilitates and supports technological progress in the national economy. In Latvia, the focus is on economic 
transformation, which involves science and technology-led development and direction towards the knowledge-based skills development. The priorities of the Strategy among others include facilitation of the production of higher-value added products, development of new products and industries with high development potential, development of modern ICT system, development of modern and futurefocused education system, developed science base.

\subsection{New Generation of Entrepreneurs}

The modern labor force, infrastructure, legal and financial frameworks do not guarantee the success of the development of advanced manufacturing. The critical element of the success of the high-tech manufacturing is the entrepreneurs - agents of innovation and creative destruction as Joseph A. Schumpeter states (McCraw, 2010).

The best definition of the entrepreneurs and their role in innovation still belongs to Joseph A. Schumpeter: "The function of entrepreneurs is to reform, or revolutionize the pattern of production by exploiting an invention, or more generally, an untried technological possibility of producing new commodity or producing an old in a new way, by opening up a new source of supply of materials or a new outlet for products by reorganizing the industry and so on" (Schumpeter, 1942). Joseph A. Schumpeter also emphasized that successful entrepreneurs have never been driven by money, but always were driven by desire and internal fire to build something new and innovative.

The government, educational institutes and media need to educate the general public and new generations about the role of the entrepreneurs in the modern society by providing stories about successful entrepreneurs in Latvia

People who want to become an entrepreneur, first need to have certain internal qualities and second understanding of the perils and consequences of this occupation. Having behind over three decades of entrepreneurship experience, it is appropriate to list the following perils of being the leader of a high-tech manufacturing start-up. A new entrepreneur, especially in such a complicated field as advanced manufacturing, needs to commit to $24 / 7$ job, without any breaks, and relatively low chances of success. It is a job to find the best possible people available and very often to fire the same people later on, people who helped at the beginning, because sometimes these people become complacent or have achieved the limit of their potential. At the same time, it is a job that requires endless patience, waiting, and high level of tolerance to other people mistakes. It is the job emotionally drained, full of self-doubt and frustration. It is the job that requires brutal honesty, towards yourself and your employees, and the job where you need to be as transparent as possible to your vendors and customers.

High-tech enterprises have comparatively low production capacities. Latvia does not have resources to succeed in the mass production consumer market. Therefore, it is necessary to focus on the niche manufacturing. The future will belong to relatively small, agile and flexible enterprises providing the original equipment manufacturers (OEM) or businesses of the world with high-end products. 
The new enterprises adapting new techniques for manufacturing will be very capital and knowledge-intensive and will require a new generation of the sophisticated labor force and new-wave entrepreneurs.

\section{CONCLUSION}

The share of the high-tech industries in exports of goods is relatively low (11.7\% in Extra-EU28 compared with EU-28 export share of 17\%). However, hightech industries in Latvia have developed quite rapidly in recent years (in the last five years, both the number of enterprises and employees have increased). In the manufacture of computer, electronic and optical products, also the value added and productivity have increased. This indicates the development opportunities, potential of these industries and the base to succeed, which is determined by the Latvian history, experience and the skilled workforce.

From all the factors that influence the development of the high-tech industries in Latvia, there are several significant factors. A part of these factors, such as stable political system, business environment, relatively low corporate income tax rate, and government support, facilitates the development of high-tech industries. There are several limiting factors, which hinder the development of the high-tech industries. The most important of those are the shortage of qualified workforce and their background (especially international marketing specialists). These factors are mainly common in all the former USSR countries.

Further development opportunities of the Latvian high-tech industries are related to the government support, including implementation of strategies, government financing, creation of incubators and supporting start-ups, facilitation of entrepreneurship and the development of entrepreneurs, bringing up and facilitating involvement of a new generation of entrepreneurs.

\section{REFERENCES}

Akamai. (2016). Q3 2016 State of the Internet - Connectivity Report, Akamai. Retrieved from https://www.akamai.com/us/en/multimedia/documents/state-of-the-internet/q3-2016-state-of-the-internetconnectivity-report.pdf

AS Grindeks. (2017). 2016.gada pārskats (Annual Report of 2016), NasdaqBaltic. Retrieved from http://www.nasdaqbaltic.com/upload/reports/grd/2016_ar_lv_eur_con_ias.pdf

Auzina-Emsina, A., \& Ozolina, V. (2017). High-Technology Industries Competitiveness and Regional Allocation by NUTS 3 Regions in Latvia. In "Research for Rural Development 2017" Annual 23rd International Scientific Conference Proceedings, May 17-19 (Vol. 2, pp. 241-248). Jelgava: Latvia University of Agriculture. http://doi.org/10.22616/rrd.23.2017.074

Basarac Sertić, M., Vučković, V., \& Škrabić Perić, B. (2015). Determinants of Manufacturing Industry Exports in European Union Member States: A Panel Data Analysis. Economic Research-Ekonomska Istraživanja, 28(1), 384-397. https://doi.org/10.1080/1331677X.2015.1043781

Colliers International. (2018). Major Investment Transactions in Commercial Real Estate in Latvia in 2017, Colliers International. Retrieved from http://www.colliers.com/enlv/latvia/insights/2018_reports_news/2018-02-08_investment_top

CSB. (2018). Statistics Database, Central Statistical Bureau of the Republic of Latvia. Retrieved from http://www.csb.gov.lv

Deloitte. (2018). Corporate Tax Rates 2018, Deloitte. Retrieved from https://www2.deloitte.com/content/dam/Deloitte/global/Documents/Tax/dttl-tax-corporate-tax-rates.pdf

Eurostat. (2018). Statistics Database, Eurostat. Retrieved from http://ec.europa.eu/eurostat/data/database

Lursoft. (2018). Annual Reports Data Base, Lursoft. Retrieved from https://www.lursoft.lv/?l=en 
McCraw, T. K. (2010). Prophet of Innovation: Joseph Schumpeter and Creative Destruction. Harvard University Press.

Ministry of Education and Science. (2013). Zinātnes, tehnologijas attīstības un inovācijas pamatnostādnes 2014. - 2020.gadam, POLSIS Politikas plānošanas dokumentu datubāze. Retrieved from http://polsis.mk.gov.lv/documents/4608

Nasdaq \& Morningstar. (2018). Company Fact Sheet: Olainfarm, Morningstar. Retrieved from http://lt.morningstar.com/gj8uge2g9k/stockprofile/default.aspx?SecurityToken=0P0000HO66\%5d3\%5d0 $\%$ 5dE0EXG\$XRIS_3113\&externalidexchange=EX \$ \$ \$XRIS\&LanguageId=enGB\&CurrencyId=EUR\&clearsession=true

Počs, R., \& Ozoliṇa, V. (2016). Latvijas ekonomikas konkurētspējas izpētes instrumentārijs [Instrumentary for Competitiveness Analysis of the Latvian Economy]. Latvijas Zinātņu Akadēmijas Vēstis, 70(3), 10-19.

Romero, J. P., \& McCombie, J. S. L. (2016). Differences in Increasing Returns between Technological Sectors: A Panel Data Investigation Using the EU KLEMS Database. Journal of Economic Studies, 43(5). http://www.doi.org/10.1108/JES-03-2015-0045

Ruan, G., \& Zhao, Y. (2011). Mechanism of High-Tech Industrial Agglomeration Growth: A View of Knowledge Spillover. In 2011 International Conference on E-Business and E-Government, ICEE2011 Proceedings. http://www.doi.org/10.1109/ICEBEG.2011.5877028

Schumpeter, J. A. (1942). Capitalism, Socialism, and Democracy. Harper\&Brothers.

Stăncioiu, A. (2017). The Fourth Industrial Revolution "Industry 4.0." Fiabilitate şi Durabilitate, 1(19), 74 78. Retrieved from http://www.utgjiu.ro/rev_mec/mecanica/pdf/2017-01/11_Alin STĂNCIOIU - THE FOURTH INDUSTRIAL REVOLUTION „INDUSTRY 4.0”.pdf

The Heritage Foundation. (2018). 2018 Index of Economic Freedom, the Heritage Foundation. Retrieved from https://www.heritage.org/index/explore?view=by-region-country-year

The World Bank. (2018). Doing Business - Measuring Business Regulations, World Bank Group. Retrieved from http://www.doingbusiness.org/

\section{AUTHORS' SHORT BIOGRAPHIES}

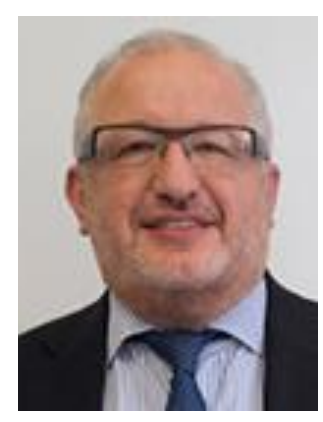

Joseph Menaker, Dr., is the Managing Director of "UAV Factory USA" LLC. He is a graduate of Latvian State University, where he received the Bachelor and Master of Science degrees in economics. In 1985, he received the Ph.D. degree in economics from Leningrad Institute of Finance and Economics.

J. Menaker started his research career at the Institute of Economics of the Latvian Academy of Sciences. He continued his research work at the NYC Department of Finance and Taxation after immigrating to the U.S. His topic of interest was the econometric modelling of regional economies.

From 1998 to 2016, he served as President of "ISP Optics Corporation" and as a Director of its wholly owned subsidiary "ISP Optics Latvia" (combined "ISP") until their purchase by "LightPath". In 2009, he co-founded "UAV Factory" in Latvia, where he serves as a Director. He also serves as a Consultant to the Board of Directors of "LightPath Technologies" and as a Board Member for the non-profit organization "Tsal Kaplun Foundation".

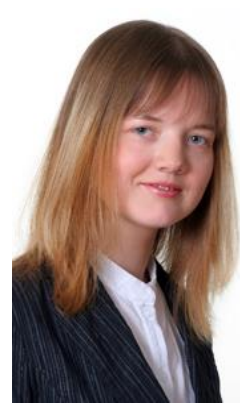

Velga Ozolina, Dr.oec., is an Associate Professor at Riga Technical University (RTU). She received the Ph.D. degree from RTU in 2010. Her major fields of study were macro-economic modelling and international economics. She has been working at RTU since 2004 and has participated in various projects related to the development of macro-economic models, forecasting of tax revenues, and analysis of international trade. In 20142018, she participated in the National Research Program "EKOSOC-LV" and analysed international competitiveness and its influencing factors. Her research interests include different aspects of international trade, tourism development, and modelling and forecasting of the national economy and its sectors. V. Ozolina is a Member of the Association of Latvian Econometrists and INFORUM (Interindustry Forecasting Project at the University of Maryland) International Partners. E-mail: Velga.Ozolina@rtu.lv

ORCID iD: https://orcid.org/0000-0002-6088-3111 